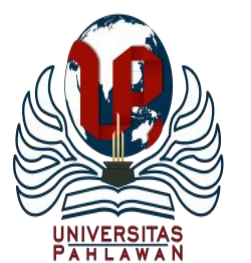

Jurnal Abdidas Volume 2 Nomor 3 Tahun 2021 Halaman 662-669

JURNAL ABDIDAS

http://abdidas.org/index.php/abdidas

\title{
Pelatihan Bisnis Online Shop dalam Membentuk Jiwa Entrepreneur Remaja Kota Prabumulih pada Masa Pandemi Covid-19
}

\author{
Rikie Dekas $^{1 \bowtie}$, Santi Oktavianti ${ }^{2}$ \\ Ekonomi Manajemen, Universitas Sumatera Selatan, Indonesia ${ }^{1,2}$ \\ E-mail: rikiedekas2021@gmail.com ${ }^{1}$, oktaviantisanti109@gmail.com $^{2}$
}

\begin{abstract}
Abstrak
Alasan dalam kegiatan pengabdian kepada masyarakat ini mengambil tema pelatihan bisnis online shop karena berdasarkan observasi dan pengamatan di lapangan, bisnis online shop sangat dibutuhkan untuk mengatasi kesulitan mencari lapangan pekerjaan di masa pandemik Covid-19. Dalam pengabdian ini, tim pelaksana ingin memberikan pelatihan agar generasi muda di Kota Prabumulih dapat hidup mandiri dengan menjadi entrepreneur. Metode dalam pengabdian kepada masyarakat ini adalah pelatihan langsung dengan menggunakan aplikasi Bisnis Online Shop. Beberapa masyarakat yang mengikuti kegiatan pengabdian kepada masyarakat sebagian adalah pedagang yang belum banyak mengenal bisnis online shop. Sehingga adanya pelatihan ini dapat menjadi solusi. Hasil dari kegiatan ini yaitu pelatihan bisnis online shop ini banyak memberikan pengalaman yang berharga kepada para peserta. Hal ini dibuktikan dengan antusias peserta yang banyak memberikan pertanyaan-pertanyaan terkait bisnis online shop. Dalam pelatihan ini, peserta tidak hanya dibimbing saja, namun juga diarahkan untuk memanfaatkan bisnis online shop agar barang dagangannya yang dijual dapat laku banyak. Di masa pandemik Covid-19 ini memang peran teknologi dalam dunia ekonomi sangat membantu sekali. Simpulan dari kegiatan pengabdian kepada masyarakat ini jelas bahwa bisnis online shop di masa pandemik Covid-19 sangat bagus diterapkan. Meskipun demikian, sistem perdagangan langsung harus masih dikembangkan. Adanya bisnis online shop ini akan membentuk jiwa generasi muda menjadi entrepreneur.
\end{abstract}

Kata kunci: pelatihan, online shop, entrepreneur, Prabumulih, pandemi

\begin{abstract}
The reason for this community service activity took the theme of Online Shop Business training because based on observations and observations in the field, the online shop business is very much needed to overcome the difficulties of finding jobs during the Covid-19 pandemic. In this service, the implementing team wants to provide training so that the younger generation in Prabumulih City can live independently by becoming entrepreneurs. This method of community service is direct training using the Online Shop Business application. Some people who take part in community service activities are traders who are not familiar with the online shop business. So this training can be a solution. The result of this activity is that the Online Shop Business training provides a lot of valuable experience to the participants. This is evidenced by the enthusiasm of the participants who gave many questions related to the online shop business. In this training, participants are not only guided, but also directed to take advantage of the online shop business so that the merchandise they sell can sell well. During the Covid-19 pandemic, the role of technology in the economy is very helpful. The conclusion from this community service activity is that it is clear that the online shop business during the Covid-19 pandemic is very well implemented. Nevertheless the direct trading system should still be developed. The existence of this online shop business will shape the soul of the younger generation to become entrepreneurs.
\end{abstract}

Keywords: training, online shop, entrepreneur, Prabumulih, pandemic

Copyright (c) 2021 Rikie Dekas, Santi Oktavianti

\begin{tabular}{l}
\hline$\square$ Corresponding author \\
Address $:$ Universitas Sumatera Selatan \\
Email $\quad:$ rikiedekas2021@gmail.com \\
DOI $\quad:$ https://doi.org/10.31004/abdidas.v2i3.332
\end{tabular}

ISSN 2721-9224 (Media Cetak)

ISSN 2721- 9216 (Media Online) 
663 Pelatihan Bisnis Online Shop dalam Membentuk Jiwa Entrepreneur Remaja Kota Prabumulih pada Masa Pandemi Covid-19 - Rikie Dekas, Santi Oktavianti

DOI: https://doi.org/10.31004/abdidas.v2i3.332

\section{PENDAHULUAN}

Indonesia merupakan negara dengan jumlah penduduk yang padat di dunia, di mana berdasarkan data Badan Pusat Statistik (BPS) pada Agustus 2017, diketahui bahwa angka pengangguran yang ada di Indonesia mencapai 7,04 juta. Hal ini dikarenakan kurangnya lapangan pekerjaan yang sesuai dengan bidang mereka dengan pendidikan yang masih belum merata. Banyak sektor pekerjaan yang mengarah pada sektor formal. Masyarakat Indonesia juga belum maksimal untuk menciptakan lapangan pekerjaan sendiri dengan berbagai alasan faktor yang menyebabkan angka pengangguran tinggi. Angka pengangguran yang sangat tinggi tersebut, menyebabkan jumlah pengangguran yang besar dan menyebabkan kurang geraknya pertumbuhan perekonomian di Indonesia. Kondisi ini dapat diketahui di beberapa kota besar dengan banyaknya penduduk pendatang yang berharap pekerjaan yang layak setiap tahunnya, namun kreativitas yang kurang menyebabkan banyak muncul pemukiman yang kumuh dan tidak layak untuk ditinggali. Jumlah pengangguran di Indonesia disebabkan antara lain pendidikan di Indonesia yang sebelumnya belum menyiapkan lulusan yang dapat menciptakan pekerjaan di era digital. Sehingga keterampilan yang didapatkan lulusan perguruan tinggi masih belum memiliki keterampilan dan pengalaman yang baik dalam menunjang ekonomi Indonesia (Hamdan, 2019).

Era digital saat ini sebenarnya adalah era yang menguntungkan bagi semua kalangan. Masyarakat Indonesia dengan bantuan teknologi dapat dengan mudah mengakses kegiatan yang sifatnya untuk mengembangkan diri. Akses jaringan internet yang semakin meluas di beberapa daerah di Indonesia menyebabkan Indonesia merupakan negara dengan dapat memungkinkan pertumbuhannya tergolong cepat. Adanya jaringan internet yang semakin diperluas di beberapa daerah ini, menyebabkan perdagangan dengan memanfaatkan akses jaringan komunikasi semakin tinggi dan memunculkan bisnis-bisnis yang baru. Masyarakat era digital harus mampu untuk melihat peluang bagaimanan era digital ini memberikan dampak yang baik bagi kemajuan sektor ekonominya. Sehingga seiring berjalannya waktu di Indonesia telah banyak ditemukan bisnis berbasis digital seperti Bukalapak, Gojek, Shoope, Tokopedia, dan lain sebagainya. Beberapa bisnis online yang tersedia untuk masyarakat Indonesia di era teknologi dan komunikasi ini adalah sebagai langkah untuk memenuhi industri perdagangan dan jasa yang selama ini semakin dibutuhkan oleh masyarakat dalam memenuhi kebutuhan seharihari secara online (Prastya Nugraha, \& Wahyuhastuti, 2017).

Di era globalisasi dengan persaingan yang sangat luas dan sangat ketat untuk menjadi pelaku ekonomi yang tanggung sangat diperlukan perjuangan yang tidak mudah. Para pelaku ekonomi yaitu masyarakat Indonesia harus mau berinovasi agar tidak tergerus oleh kemajuan zaman yang semakin canggih. Pemanfaatan teknologi dalam bidang ekonomi yang tepat akan membentuk jiwa entrepreneur yang baik untuk masa depan dalam mengoptimalkan keadaan yang ada dari unit-unit usaha yang dikembangkan. Kolaborasi antara manusia dan teknologi dalam 
664 Pelatihan Bisnis Online Shop dalam Membentuk Jiwa Entrepreneur Remaja Kota Prabumulih pada Masa Pandemi Covid-19 - Rikie Dekas, Santi Oktavianti

DOI: https://doi.org/10.31004/abdidas.v2i3.332

menciptakan peluang usaha yang mampu berdiri sendiri dalam bersaingan dunia, akan menjadi landasan kemajuan ekonomi bangsa. Untuk membangun manusia yang entrepreneur dibutuhkan semangat yang baik, dengan semangat untuk membangun usaha. Maka dengan semangat yang tinggi tidak mengherankan jika berbagai unit usaha baru dapat tumbuh dengan memanfaatkan teknologi aplikatif dalam proses inovasi, produksi, marketisasi, dan lain sebagainya. Teknologi dalam membangun ekonomi di dunia telah banyak diakui sebagai salah satu langkah untuk mengatasi permasalahan-permasalahan dunia (Permana, 2021).

Generasi muda saat ini telah banyak mengenal teknologi sebagai penunjang kehidupannya. Sehingga generasi muda lebih dikenal dengan manusia teknologi. Namun sampai berapa manfaat yang digunakan dalam menggunakan teknologi tersebut, tentunya membutuhkan kebijakan dalam penggunaannya. Apalagi jika teknologi dikaitkan dengan permasalahan ekonomi saat ini. Tentu sangat menarik oleh karena masyarakat Indonesia adalah masyarakat yang berbasis digital. Pada masyarakat Kota Prabumulih sendiri, generasi muda maupun tua telah banyak memanfaatkan teknologi sebagai penunjang kehidupannya. Namun permasalahan ekonomi masih sering menjadi kendala dalam menentukan kehidupannya. Di masa pandemik Covid-19 banyak sistem kegiatan yang dibatasi termasuk pelaku ekonomi. Hal ini tentunya kurang menguntungkan bagi masyarakat yang bergerak di bidang perekonomian dan jasa. Untuk itu, tim pelaksana yang merupakan Dosen Ekonomi di
Universitas Sumatera Selatan berusaha untuk mengajak para pelaku ekonomi memanfaatkan teknologi untuk membentuk jiwa entrepreneur melalui bisnis online shop.

\section{METODE}

Pelaksanaan kegiatan pengabdian kepada masyarakat ini dilakukan selama dua hari. Pelaksanaannya dimulai pada hari Rabu-Kamis tanggal 2-3 Juni 2021. Dalam pelaksanaan kegiatan ini dilaksanakan di Kompleks Perumahan, Jalan Cendrawasih, RT 01 RW 01, Kelurahan Gunung Ibul Prabumulih Timur. Kegiatan pengabdian kepada masyarakat ini, dilaksanakan dengan diawali dengan memberikan ceramah dalam bentuk Pelatihan Bisnis Online Shop dalam Membentuk Jiwa Entrepreneur untuk Remaja pada Masa Pandemik, di mana jumlah pesertanya mencapai 15 orang peserta yang terdiri dari remaja SMA dan orang tua. Ketua RT selaku pimpinan masyarakat sekitar kompleks memberikan kontribusi tempat pelaksanaan di Balai Kompleks yang luas untuk dilaksanakan kegiatan pengabdian kepada masyarakat.

Metode dalam kegiatan pengabdian kepada masyarakat yang dilaksanakan oleh tim pelaksana meliputi, yaitu:

\section{Tahapan Perencanaan dan Persiapan}

Pada tahapan ini merupakan langkah di mana sebelum melaksanakan pelatihan. Pada tahapan awal untuk memberikan pelatihan diawali dengan melakukan perencanaan kegiatan, yang selanjutnya melaksanakan survei dan melaksanakan wawancara terbatas terkait permasalahan yang dialami oleh mitra. Dalam 
665 Pelatihan Bisnis Online Shop dalam Membentuk Jiwa Entrepreneur Remaja Kota Prabumulih pada Masa Pandemi Covid-19 - Rikie Dekas, Santi Oktavianti

DOI: https://doi.org/10.31004/abdidas.v2i3.332

pengabdian kepada masyarakat ini mitra yang menjalin kerjasama adalah Ketua RT kompleks Perumahan di Kota Prabumulih. Tahapan ini berusaha untuk mendapatkan data terkait perkembangan ekonomi di kompleks tersebut di masa pandemik. Setelah data didapatkan langkah selanjutnya kesepakatan bersama mitra untuk melaksanakan kegiatan Pelatihan Bisnis Online Shop dalam Membentuk Jiwa Entrepreneur untuk Remaja pada Masa Pandemik.

\section{Tahapan Pelaksanaan Pelatihan dan Diskusi}

Kegiatan pengabdian kepada masyarakat ini, dilaksanakan dengan diawali dengan memberikan ceramah dalam bentuk Pelatihan Bisnis Online Shop dalam Membentuk Jiwa Entrepreneur untuk Remaja pada Masa Pandemik, di mana jumlah pesertanya mencapai 15 orang peserta yang terdiri dari remaja SMA dan orang tua. Ketua RT sekalu pimpinan masyarakat sekitar kompleks memberikan kontribusi tempat pelaksanaan di Balai Kompleks yang luas untuk dilaksanakan kegiatan pengabdian kepada masyarakat. Kegiatan ini dilaksanakan secara tatap muka dengan tetap menaati protokol kesehatan. Kerjasama antara tim pelaksana dan penyelenggara sekitar kompleks tentunya harus berdasarkan keadaan yang terjadi saat ini. Para peserta dan tim pelaksana yang ada di lokasi harus memakai masker dan menjaga jarak. Penyelenggara sendiri tetap menyediakan air cuci tangan dan sabun, serta masker bagi masyarakat yang belum menggunakan masker.

Adapun materi yang diberikan oleh tim pelaksana pengabdian kepada masyarakat adalah mulai dari potensi remaja masa kini, teknologi, jaringan dan pemanfaatan media sosial sebagai bisnis online shop. Kegiatan ini untuk menumbuhkan pemahaman baru agar generasi muda tidak hanya bergantung pada posisi yang ada saat ini. Generasi muda harus lebih berani dalam tampil untuk menunjukkan kemampuannya. Meskipun demikian, tetap harus memperhitungkan dampak positif dan negatif yang terjadi jika salah mempergunakan teknologi dalam berbisnis. Peluang dalam pemanfaatan bisnis online shop sebagai penunjang ekonomi baru jelas dilihat dari potensi generasi muda yang cerdas. Saat ini generasi muda telah banyak memanfaatkan teknologi untuk kehidupan sehari-harinya. Maka dituntut masyarakat yang kreatif dan inovatif dalam memanfaatkan media tersebut.

Pada tahapan yang terakhir adalah memberikan evaluasi terkait pelatihan bisnis online shop bagi remaja di Kota Prabumulih. Bahan evaluasi yang dijadikan acuan dalam metode ini adalah melalui tanya jawab dengan peserta yang kemudian dijabarkan melalui sebuah kesimpulan untuk mendapatkan jawaban dari kegiatan pengabdian kepada masyarakat di Kota Prabumulih yang nantinya akan berdampak positif bagi pembentukan jiwa entrepreneur bagi kalangan remaja.

\section{HASIL DAN PEMBAHASAN}

Dalam mengembangkan bakat dalam jiwa generasi muda untuk dapat memiliki jiwa enterpreneur adalah langkah yang positif karena jumlah wirausahawan muda yang masih sangat minim. Padahal kemajuan teknologi yang semakin canggih sudah selayaknya untuk terus ditingkatkan kemampuan lapangan generasi muda untuk tidak 
666 Pelatihan Bisnis Online Shop dalam Membentuk Jiwa Entrepreneur Remaja Kota Prabumulih pada Masa Pandemi Covid-19 - Rikie Dekas, Santi Oktavianti

DOI: https://doi.org/10.31004/abdidas.v2i3.332

tergantung akan keadaan. Saat ini juga dalam sistem perdagangan masyarakat telah dikenal dengan sistem online. Banyak situs-situs online yang dapat dipergunakan untuk menunjang kehidupan masyarakat. Sistem pembelajaran online saat ini lebih disukai karena tanpa harus datang ke toko si penjual. Maka pelatihan bisnis online shop sangat menarik jika diterapkan bagi masyarakat terutama generasi muda masa kini (Andriana dan Finnah Fourqoniah, 2020).

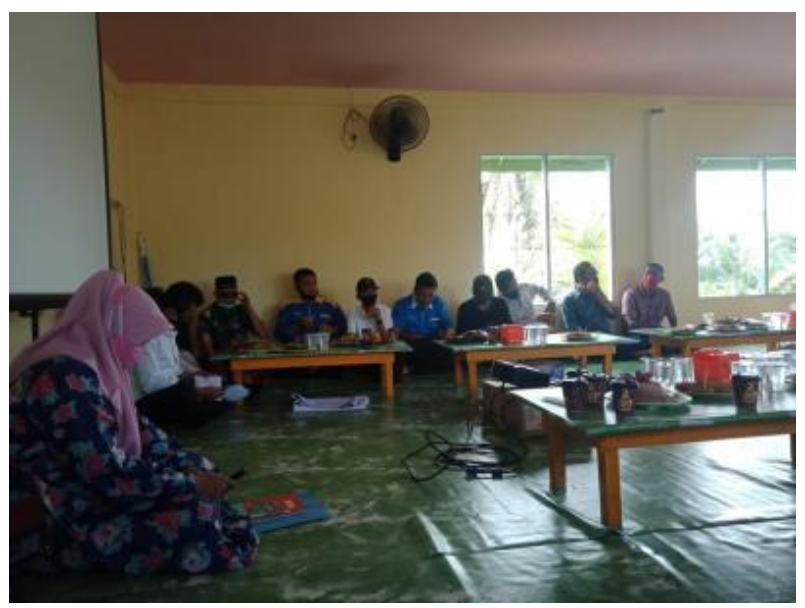

Gambar 1. Pembukaan Pelatihan Bisnis Online Shop

Keunggulan dalam memberikan pelatihan bisnis online shop agar tercipta generasi muda yang memiliki jiwa entrepreneur sangat penting sekali di masa pandemik seperti saat ini. Hal ini penting agar masyarakat Indonesia di daerah dapat memiliki rasa tanggung jawab yang tinggi dalam pembangunan ekonomi yang semakin maju. Masyarakat Indonesia dituntut agar dapat lebih terampil dalam mengembangkan bakatnya agar tidak tergantung pada lowongan pekerjaan yang ada saat ini. Pelatihan yang dikembangkan tentunya memiliki sifat yang disesuaikan dengan keadaan masyarakat dan perkembangan zaman yang semakin canggih. Pelatihan memiliki tiga cakupan, yaitu: penyadaran, pembangunan kapasitas, dan pendayaan.

Pada langkah pertama yang harus dilakukan, yaitu: penyadaran, yaitu masyarakat harus memiliki sebuah target dalam pengembangkan hak-hak yang selayaknya dimiliki. Pada kegiatan ini adalah pengetahuan yang sifatnya kognisi, kepercayaan, dan penyembuhan. Pada langkah kedua, yaitu usaha dalam meningkatkan kapasitas atas kemampuan yang dimilikinya. Peningkatan dalam sebuah kapasitas tersebut meliputi: manusia, organisasi, dan sistem nilai. Pada bagian terakhir, yaitu berkaitan dengan pendayaan yang meliputi daya, kekuasaan, otoritas, atau peluang dalam mengembangkan kemampuannya. Meskipun demikian sebenarnya peran pemerintah dalam mengembangkan kemampuan dalam membangun masyarakat Indonesia sangat diharapkan. Namun tetap harus dimengerti, masyarakat Indonesia tetap harus mampu menunjukkan jiwa-jiwanya yang mandiri dengan berbagai kegiatan yang menunjang kehidupannya (Aflahah dan Mohammad Imam Sufiyanto, 2019).

Pada kegiatan pengabdian kepada masyarakat ini dilaksanakan pada tanggal 02 Juni 2021 dengan tema Pelatihan Bisnis Online Shop dalam Membentuk Jiwa Entrepreneur Remaja Kota Prabumulih pada Masa Pandemik Covid-19, pelaksanaan kegiatan pengabdian kepada masyarakat ini berada di Balai Komplek Perumahan Kota Prabumulih. Peserta dalam kegiatan ini dibatasi karena masih dalam masa pandemik dengan jumlah peserta sebanyak 15 
667 Pelatihan Bisnis Online Shop dalam Membentuk Jiwa Entrepreneur Remaja Kota Prabumulih pada Masa Pandemi Covid-19 - Rikie Dekas, Santi Oktavianti

DOI: https://doi.org/10.31004/abdidas.v2i3.332

orang peserta. Setiap peserta kegiatan diwajibkan untuk memakai masker dan menjaga jarak. Panitia pelaksana menyediakan sabun cuci tangan, air mengalir, dan tisu untuk keperluan sebelum masuk ke tempat acara. Acara yang sederhana ini sangat memberikan manfaat bagi masyarakat Prabumilih yang menjadi bagian dalam kegiatan pelatihan tersebut. Diharapkan pada akhirnya nanti pelatihan ini dapat memberikan pengalaman yang berharga bagi para peserta untuk menjadi entrepreneur yang mandiri dan sukses di masa depan.

Selama ini masyarakat Prabumulih, khususnya generasi muda telah banyak berpendidikan, namun belum banyak yang dapat membentuk pekerjaan sendiri. Kebanyakan masyarakat masih tergantung pada lowongan pekerjaan yang ada. Adanya pelatihan ini sungguh sangat menarik sekali bagi pengembangan pengetahuan masyarakat.

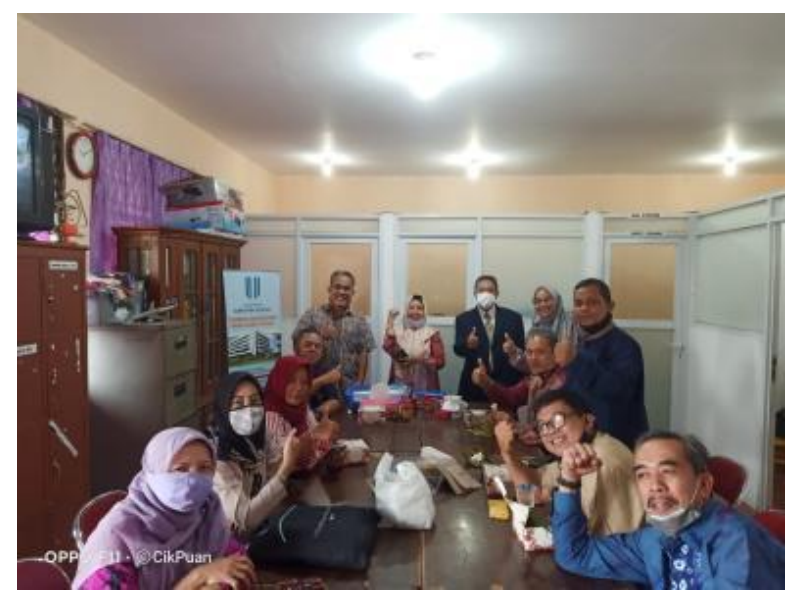

Gambar. 2. Antusias Peserta Kegiatan Pelatihan

Beberapa langkah pelatihan bisnis online shop untuk menjadi entrepreneur, yaitu sebagai berikut:
Tabel 1. Langkah Kegiatan Pengabdian

\begin{tabular}{|c|c|}
\hline No & $\begin{array}{l}\text { Beberapa Langkah Kegiatan Pengabdian } \\
\text { Melalui Pelatihan Bisnis Online Shop }\end{array}$ \\
\hline 1 & $\begin{array}{l}\text { Tahapan Persiapan, yaitu melakukan studi } \\
\text { observasi terkait bisnis yang sedang } \\
\text { dikembangkan oleh para peserta pelatihan. Hal } \\
\text { ini penting untuk mengetahui gambaran } \\
\text { keadaan peserta sebelum nanti materi } \\
\text { disampaikan. }\end{array}$ \\
\hline 2 & $\begin{array}{l}\text { Tahapan Pelaksanaan Pelatihan, yaitu usaha } \\
\text { dalam mengumpulkan peserta mengenai } \\
\text { maksud dari pelatihan yang akan diajarkan } \\
\text { kepada peserta. Pada pelatihan ini hal } \\
\text { terpentingnya adalah memberikan semangat } \\
\text { dan peluang agar dalam berbisnis online dapat } \\
\text { dikembangkan secara inovatif dan kreatif } \\
\text { meskipun dalam masa pandemik. }\end{array}$ \\
\hline 3 & $\begin{array}{l}\text { Tahapan Testing dan Sharing, yaitu pada } \\
\text { tahapan ini tim pelaksana berusaha untuk } \\
\text { mengidentifikasi jenis produk yang ditawarkan } \\
\text { melalui bisnis online shop untuk menentukan } \\
\text { strategi penjualan yang dapat meningkatkan } \\
\text { omset penjualan. }\end{array}$ \\
\hline 4 & $\begin{array}{l}\text { Tahapan Evaluasi, yaitu dilakukan untuk } \\
\text { mengukur tingkat keberhasilan dalam } \\
\text { pelaksanaan pelatihan yang diberikan dengan } \\
\text { keterlibatan dan antusias peserta selama } \\
\text { pelatihan. Evaluasi ini penting untuk koreksi } \\
\text { penjualan lanjutan yang akan dikembangkan } \\
\text { selanjutnya di masa pandemik Covid-19. }\end{array}$ \\
\hline
\end{tabular}

Pelaksanaan kegiatan pengabdian kepada masyarakat ini secara umum berjalan sesuai dengan target yang telah ditetapkan di awal, mulai dari perencanaan kegiatan, survei ke lokasi sampai kegiatan berlangsung. Perangkat pemukiman yang terdiri dari Ketua RT setempat dan masyarakat sekitar kompleks di Prabumulih sangat antusias dalam mengikuti kegiatan pengabdian kepada masyarakat. Banyak sekali diskusi terkait potensi bisnis online shop saat ini ditengah pandemik Covid-19 yang menghasilkan banyak argumen positif yang membangun. Meskipun demikian, tim pengusul pengabdian kepada masyarakat masih memiliki banyak kendala dalam hal teknis, seperti kegiatan pengabdian kepada masyarakat tersebut 
668 Pelatihan Bisnis Online Shop dalam Membentuk Jiwa Entrepreneur Remaja Kota Prabumulih pada Masa Pandemi Covid-19 - Rikie Dekas, Santi Oktavianti

DOI: https://doi.org/10.31004/abdidas.v2i3.332

harus tetap terus dilaksanakan secara berkala sampai masyarakat kompleks dapat mandiri dalam kelanjutannya.

Melalui kegiatan pelatihan bisnis online shop yang dilakukan tim pelaksana dari Dosen Ekonomi Manajemen Universitas Sumatera Selatan banyak masyarakat terutama generasi muda lebih memahami fungsi media sosial untuk bisnis yang baik. Pelatihan ini juga dilaksanakan dengan praktik langsung untuk memperdagangkan jualan masyarakat secara online. Pengalaman mengikuti pelatihan ini tidak dapat dilupakan oleh peserta kegiatan yang sangat antusias dalam mengikuti kegiatan selama dua hari. Masyarakat yang berpartisipasi melalui kegiatan ini berusaha untuk menerapkan bisnis online shop di dalam rumahnya.

Pada dasarnya masyarakat kompleks di Perumahan Kota Prabumulih sangat antusias dengan kehadiran kami tim pengabdian kepada masyarakat yang telah memberikan pelatihan bisnis online shop kepada masyarakat di masa pandemik Covid-19. Selain itu, kendala yang sangat mempengaruhi kegiatan ini adalah anggaran yang dianggarkan dinilai sangat kurang. Hal ini didasarkan atas sebab program pengabdian kepada masyarakat ini dilaksanakan kurang pengalaman yang umumnya terbiasa bekerja di pabrik dan harus menuntut kesabaran dan bimbingan secara berkala. Oleh karena keterbatasan biaya tersebut, kegiatan ini hanya dilakukan dalam bentuk pelatihan bisnis online shop bagi masyarakat di masa pandemik Covid-19.

\section{SIMPULAN}

Dalam kegiatan pelatihan ini sangat penting untuk dilaksanakan sebagai langkah membentuk generasi muda di Kota Prabumulih yang berjiwa entrepreneur atau mampu untuk berwirausaha. Dalam pelatihan ini banyak antuasias yang diberikan peserta dengan baik. Di era globalisasi seperti saat ini, masyarakat Indonesia harus mampu terampil dalam menawarkan barang dagangannya. Saat ini Indonesia dan dunia juga masih dalam suasana pandemik Covid-19 yang memberikan pengaruh sangat besar bagi perekonomian Indonesia. Adanya kegiatan pengabdian kepada masyarakat tentang pelatihan bisnis online shop tentunya akan menambah wawasan bagi para pengembang ekonomi melalui perdagangan online. Tim pelaksana pengabdian kepada masyarakat juga akan memberikan pelatihan tambahan menjelang selesainya kegiatan. Pelatihan lanjutan ini dapat berupa online maupun tatap muka terbatas seperti yang dilakukan pada saat kegiatan berlangsung saat ini. Hal ini agar pelatihan yang dilakukan dapat diterapkan dan menjadi solusi bagi kegiatan ekonomi masyarakat tersebut.

\section{UCAPAN TERIMA KASIH}

Pengabdian kepada masyarakat merupakan kegiatan wajib dalam bidang Tri Darma Perguruan Tinggi dalam kegiatan pengabdian kepada masyarakat ini, tim pelaksana mengucapkan kepada beberapa pihak yang mendukung dalam kegiatan ini sehingga kegiatan pengabdian ini dapat berhasil. Ucapan terima kasih kami haturkan kepada 
669 Pelatihan Bisnis Online Shop dalam Membentuk Jiwa Entrepreneur Remaja Kota Prabumulih pada Masa Pandemi Covid-19 - Rikie Dekas, Santi Oktavianti

DOI: https://doi.org/10.31004/abdidas.v2i3.332

1. Pihak Universitas Sumatera Selatan yang telah memberikan dorongan agar dosen menjadi lebih aktif dan kreatif dalam melaksanakan Tri Darma Perguruan Tinggi.

2. Anggota Tim Pelaksana yang senantiasa membantu kegiatan dari awal sampai selesai.

3. Pihak penyelenggara yang telah memberikan kesempatan untuk memberikan pelatihan terbaik bisnis online shop bagi remaja di Prabumulih.

\section{DAFTAR PUSTAKA}

Aflahah dan Mohammad Imam Sufiyanto. (2019). Pelatihan Kewirusahaan Berbasis Internet: Tips dan Trik Sukses Berbisnis Online Bagi Remaja Milenial di Desa Kaduara Barat Pamekasan. Perdikan: Journal of Community Engagement, 1(2), 77-83. https://doi.org/https://doi.org/10.19105/pjce.v $1 \mathrm{i} 2.2661$

Andriana, A. N. dan F. F. (2020). Pengembangan Jiwa Entrepreneur Dalam Meningkatkan Jumlah Wirausaha Muda. JURNAL PLAKAT Jurnal Pelayanan Kepada Masyarakat, 2(1), 43-51.

https://doi.org/http://dx.doi.org/10.30872/pla kat.v2i1.3823

Hamdan. (2019). Model Pengembangan Kreativitas dan Inovasi dalam Membentuk Entrepreneur di Era Ekonomi Digital. Jurnal Manajemen Dan Kewirausahaan, 7(1), 59$68 . \quad$ Retrieved from http://jurnal.unmer.ac.id/index.php/jmdk/artic le/view/2548

Permana, Asep Yudi, D. (2021). Pelatihan Technopreneur Calon Arsitek Dalam Membangun Jiwa Wirausaha. Lentera Karya Edukasi, 1(1), 16-24. Retrieved from https://ejournal.upi.edu/index.php/Lentera/art icle/view/33471

Prastya Nugraha, A. E., \& Wahyuhastuti, N. (2017). Start Up Digital Business: Sebagai
Solusi Penggerak Wirausaha Muda. JURNAL NUSANTARA APLIKASI MANAJEMEN BISNIS, 2(1), 1-9. https://doi.org/https://doi.org/10.29407/nusa mba.v2i1.701 